\title{
Hubungan Dukungan Sosial dan Efikasi Diri terhadap Motivasi Berprestasi Siswa SMA
}

\author{
Yeni Puspitasari*, Blasius Boli Lasan, Arbin Janu Setiyowati \\ Universitas Negeri Malang, Jl. Semarang No. 5 Malang, Jawa Timur, Indonesia \\ *Penulis korespondensi, Surel: puspitasari.1701116@students.ac.id
}

Paper received: 28-9-2021; revised: 12-10-2021; accepted: 19-10-2021

\begin{abstract}
This study aims to determine: (1) the relationship of social support to achievement motivation; (2) The relationship of self-efficacy to achievement motivation; (3) The relationship between social support and self-efficacy on achievement motivation (4) The amount of the independent variable's contribution to the dependent. The design of this research is social support and self-efficacy as independent variables, while achievement motivation is the dependent variable. The research population of SMAN 1 Wates students with a sample of 183 students obtained through simple random sampling technique. The research instrument used consisted of a social support scale, a self-efficacy scale, and an achievement motivation scale. The data analysis technique was in the form of descriptive statistics with the results obtained on the social support variable having a percentage value of 74.3 percent in the high category, while in the medium category it was 25.7 percent. The results of self-efficacy get a score of 83.6 percent in the high category, and 16.4 percent in the medium category. Achievement motivation has a value of 79.8 percent, while in the medium category it is 20.2 percent. Then, the effect of the predictor variable on the criteria is 45.4 percent. Overall, it can be seen that there is a significant and positive relationship between social support and self-efficacy together with achievement motivation.
\end{abstract}

Keywords: social support; self-efficacy; achievement motivation

\begin{abstract}
Abstrak
Penelitian ini bertujuan untuk mengetahui: (1) Hubungan dukungan sosial terhadap motivasi berprestasi; (2) Hubungan efikasi diri terhadap motivasi berprestasi; (3) Hubungan dukungan sosial dan efikasi diri terhadap motivasi berprestasi (4) Besarnya sumbangan variabel independen terhadap dependen. Rancangan penelitian ini yaitu dukungan sosial dan efikasi diri sebagai variabel bebas, sedangkan motivasi berprestasi sebagai variabel terikat. Populasi penelitian siswa SMAN 1 Wates dengan sampel 183 siswa yang diperoleh melalui teknik simple random sampling. Instrumen penelitian yang digunakan terdiri dari skala dukungan sosial, skala efikasi diri, dan skala motivasi berprestasi. Teknik analisis data berupa statistik deskriptif dengan hasil yang diperoleh pada variabel dukungan sosial mempunyai persentase nilai 74,3 persen kategori tinggi, sedangkan pada kategori sedang 25,7 persen. Hasil dari Efikasi diri mendapatkan nilai sebesar 83,6 persen kategori tinggi, dan kategori sedang 16,4 persen. Motivasi berprestasi memiliki nilai sebesar 79,8 persen, sedangkan pada kategori sedang 20,2 persen. Kemudian, untuk pengaruh variabel prediktor terhadap kriterium yaitu 45,4 persen. Secara keseluruhan dapat diketahui bahwa terdapat hubungan yang signifikan dan positif antara dukungan sosial dan efikasi diri secara bersama-sama terhadap motivasi berprestasi.
\end{abstract}

Kata kunci: dukungan sosial; efikasi diri; motivasi berprestasi

\section{Pendahuluan}

Pendidikan diartikan sebagai suatu pengalaman yang menjadikan siswa mampu berkembang dan bertumbuh melalui pengertian, pemahaman, dan penyesuaian yang diperoleh dari suatu proses yang dikemukakan oleh Crow \& Crow (dalam Suriansyah, 2011). Ketika berada di masa SMA, remaja sedang mengalami berbagai perubahan menuju pribadi 
yang lebih matang. Menurut Hurlock (1980) masa remaja merupakan periode yang penting, karena dampak dari masa ini akan berakibat secara langsung maupun jangka panjang. Oleh karena itu, penting bagi siswa memiliki semangat belajar yang tinggi, umumnya semangat belajar berasal dari motivasi. Santrock (2003) menjelaskan bahwa bisa atau tidaknya remaja beradaptasi dengan akademis dan tekanan dari lingkungan besar ditentukan dari faktor motivasi dan psikologis. Motivasi berprestasi menurut Mcclelland (dalam Susanto, 2018) merupakan daya penggerak seseorang untuk menangani berbagai tantangan dan rintangan dalam meraih tujuan.

Selama melaksanakan studi pendahuluan tentang motivasi berprestasi siswa, informasi yang didapatkan oleh peneliti dari wawancara guru BK di Sekolah SMAN 1 Wates Kabupaten Kediri bahwa masalah yang seringkali terjadi yaitu tidak mengerjakan tugas dari guru, kurang adanya inisiatif, malas belajar, tidak mengikuti kelas dan suasana hati yang sering berubahubah yang berdampak pada kegiatan belajar. Selain itu, kegiatan belajar yang harus dialihkan secara daring membuat siswa kurang memahami materi, sehingga pekerjaan semakin menumpuk. Permasalahan-permasalahan ini terjadi karena motivasi berprestasi siswa yang rendah dalam bidang belajar, sehingga kegiatan belajar di sekolah diabaikan yang berdampak pada nilai yang diperoleh kurang maksimal dan mendapatkan sanksi dari guru.

Data yang diperoleh dari sekolah tersebut diperjelas dengan adanya informasi yang disampaikan oleh Presiden Jokowi berdasarkan skor Programme For International Student Assessment (PISA). Presiden Jokowi menyebutkan di tahun 2018 Indonesia menunjukkan penurunan pada beberapa bidang, selain itu diketahui terdapat tiga permasalahan pendidikan yaitu tingginya persentase siswa berprestasi rendah, siswa mengulang kelas, dan tingkat ketidakhadiran di kelas (Intan, 03 April 2020). Data ini menunjukkan bahwa pendidikan di Indonesia perlu diperhatikan dan dibenahi agar memiliki generasi unggul. Selain itu, pandemi covid-19 juga berdampak pada dunia pendidikan yang mana sebanyak 40\% pelajar kehilangan motivasi belajar (Rosa dan Efendi, 16 Desember 2020). Hal ini menginformasikan bahwa adanya covid-19 berdampak pada pendidikan, siswa yang belum terbiasa dengan pembelajaran secara daring membuat motivasi belajar yang dapat menghasilkan siswa berprestasi masih rendah.

Penelitian dari Nate (2019) menyebutkan siswa di SMA Perguruan Rakyat 2 yang tingkat prestasinya rendah dalam akademik disebabkan oleh beberapa faktor. Berikut faktor penyebab pada siswa tersebut yaitu kurangnya dukungan dan perhatian dari orang tua maupun teman, mengerjakan tugas atau belajar bukan dari kesadaran diri sendiri namun karena takut dengan guru dan tugas kelompok. Pemaparan ini menunjukkan bahwa siswa yang kurang berminat dalam akademik dilatar belakangi dari lingkungan dan pribadi siswa. Penelitian lain dari Budiarto (2019) menjelaskan tentang motivasi berprestasi pada siswa yang memiliki orang tua tunggal. Pada penelitian ini, siswa dengan orang tua tunggal saat mengalami rasa tertekan dan tidak nyaman dapat berdampak pada aktivitas yang dilakukan seperti tidak fokus saat belajar di sekolah. Selain itu, siswa tetap menyadari pentingnya memperjuangkan masa depan dan bangkit dari keadaan tersebut.

Pada studi pendahuluan terdahulu tentang motivasi berprestasi siswa SMA dapat dipengaruhi oleh banyak faktor, salah satu faktornya tentang perhatian dari lingkungan siswa. Perhatian yang diberikan oleh lingkungan dapat berupa dukungan yang diberikan oleh seseorang maupun kelompok pada siswa, sehingga dapat memberikan dorongan dalam meraih 
prestasi. Selain itu, motivasi berprestasi siswa SMA berasal dari pribadi individu. Hurlock (1980) juga menjelaskan bahwa di masa ini siswa memiliki keinginan yang tidak realistik sehingga dapat mengakibatkan kegagalan. Berbagai peristiwa yang kurang menyenangkan akan berdampak pada diri siswa, yang mana akan muncul keraguan terhadap diri sendiri. Berdasarkan paparan tersebut, maka dibutuhkan keyakinan terhadap kemampuan diri sendiri yang biasa disebut sebagai efikasi diri.

Penjelasan sebelumnya dapat diketahui bahwa adanya urgensi pada siswa SMA untuk menanamkan motivasi berprestasi dalam diri masing-masing. Hurlock (1980) menjelaskan bahwa masa SMA merupakan masa untuk mulai memikirkan masa depan secara sungguhsungguh. Penelitian ini bertujuan sebagai penunjang atau menambah informasi bagi guru BK dalam menyusun program bimbingan dan konseling, sedangkan fungsi layanan ini untuk mengembangkan minat siswa dalam mencetak prestasi yang mana disampaikan guru BK saat memberikan layanan dasar. Urgensi lain dari penelitian ini yaitu layanan yang disampaikan guru BK mampu mempengaruhi siswa menjadi pribadi yang lebih matang dalam menghadapi kehidupan di masa berikutnya dan tugas perkembangan siswa pada periode ini dapat tercapai.

Berdasarkan persoalan atau permasalahan yang terjadi di dunia pendidikan dan penelitian-penelitian terdahulu yang telah dipaparkan. Peneliti tertarik untuk melaksanakan penelitian dalam rangka mengetahui hubungan dari beberapa variabel. Variabel yang menjadi fokus penelitian terdiri dari dukungan sosial, efikasi diri, dan motivasi berprestasi. Tujuan penelitian ini adalah untuk mengetahui hubungan dukungan sosial dan efikasi diri dengan motivasi berprestasi siswa SMAN 1 Wates Kediri.

\section{Metode}

Sebagai tindak lanjut suatu penelitian, desain penelitian yang digunakan yaitu deskriptif korelasional dengan jenis penelitian ex post facto. Jangka waktu yang digunakan untuk melakukan penelitian kurang lebih sekitar 3 bulan mulai dari wawancara guru BK hingga penyebaran angket pada siswa. Pengukuran menggunakan skala pada masing-masing variabel yang dikembangkan oleh peneliti. Kemudian untuk cara pengisian angket dilakukan melalui google form. Populasi penelitian yaitu siswa SMAN 1 Wates dengan teknik penarikan sampel yaitu simple random sampling melalui rumus issac \& michael yang menghasilkan jumlah sampel sebesar 183 siswa. Sebelum melakukan penelitian, maka dilakukan uji coba instrumen melalui uji validitas dan reliabilitas. Hasil nilai reliabilitas diperoleh dari alpha cronbach yaitu 0,859 variabel dukungan sosial, 0,880 variabel efikasi diri, 0,764 variabel motivasi berprestasi. Sementara itu, uji validitas pada penelitian ini akan dikatakan valid jika nilai sig $<0,05$. Berdasarkan nilai yang ditetapkan, maka item-item pertanyaan harus dibuang apabila tidak memenuhi syarat. Tahap akhir, melakukan analisis data menggunakan statistik deskriptif.

\section{Hasil dan Pembahasan}

\subsection{Hasil}

Hasil uji korelasi berganda, yang mana diketahui bahwa diperoleh nilai probabilitas (sig F change $=0,001$ karena nilai sig. $F$ change $0,001<0,05$, artinya terdapat hubungan signifikan antara dukungan sosial dan efikasi diri terhadap motivasi berprestasi. Selain itu, nilai $\mathrm{R}$ atau koefisien korelasi menunjukkan angka 0,674 sehingga apabila dilihat dari pedoman derajat hubungan korelasi nilai 0,61-0,80 memiliki korelasi dengan kategori kuat. Berdasarkan analisis tersebut, dapat disimpulkan bahwa terdapat hubungan yang kuat antar variabel yang 
diteliti. Selain itu, berdasarkan rumus dari persamaan regresi yaitu $\mathrm{Y}=\mathrm{a}+\mathrm{b} 1 \mathrm{X} 1+\mathrm{b} 2 \mathrm{X} 2$, hasil yang diperoleh yaitu $14.620+0,244 \mathrm{X} 1+0,519 \mathrm{X} 2$.

Selanjutnya, dilakukan uji $\mathrm{F}$ dengan dasar ketentuan nilai sig $<0,05$ atau $\mathrm{F}$ hitung $>\mathrm{F}$ tabel maka dapat diartikan adanya pengaruh pada variabel $\mathrm{X}$ secara simultan terhadap variabel Y. Diketahui bahwa nilai signifikansi $0,001<0,05$ serta nilai $F$ hitung dan $F$ tabel yaitu $74,979>3,05$. Setelah diketahui nilai pokok dalam analisis uji F, dapat disimpulkan bahwa terdapat hubungan antara dukungan sosial dan efikasi diri secara simultan terhadap motivasi berprestasi.

Kemudian, setelah dilakukan uji F peneliti melaksanakan uji T dengan ketentuan nilai sig $<0,05$, atau $t$ hitung $>\mathrm{t}$ tabel maka terdapat pengaruh variabel $\mathrm{X}$ terhadap variabel $\mathrm{Y}$. Variabel dukungan sosial (X1) memiliki nilai signifikansi $0,001<0,05$ serta nilai t hitung dan $t$ tabel yaitu 3,864 >1,97323 sehingga dapat disimpulkan bahwa dukungan sosial (X1) memiliki hubungan terhadap motivasi berprestasi (Y). Sementara itu, nilai yang terdapat pada variabel efikasi diri memiliki signifikansi sebesar 0,001 <0,05 serta t hitung dan t tabel yaitu 8,207 > 1,97323 sehingga dapat disimpulkan bahwa efikasi diri (X1) memiliki pengaruh terhadap motivasi berprestasi (Y).

Setelah diketahui pengaruh dari masing-masing variabel, peneliti melanjutkan penggalian data terkait hasil koefisien determinasi $\left(R_{2}\right)$ dengan perolehan nilai R square 0,454 atau sama dengan 45,4\%. Data tersebut menunjukkan bahwa dukungan sosial (X1) dan efikasi diri (X2) secara simultan berhubungan dengan motivasi berprestasi Y sebesar 45,4\%, sedangkan besar hubungan variabel motivasi berprestasi yang ditimbulkan oleh faktor lain sebanyak $54,6 \%$.

\subsubsection{Tahap I Persiapan}

Pada tahap ini, peneliti akan melakukan beberapa hal untuk menyukseskan penyelenggaraan penelitian di SMAN 1 Wates. Di mulai dengan membuat surat penelitian dari fakultas yang kemudian diserahkan pada sekolah. Setelah mendapat persetujuan dari pihak sekolah peneliti melakukan wawancara bersama guru BK terkait permasalahan yang dialami oleh siswa secara umum. Berdasarkan informasi tersebut, peneliti mengembangkan penelitian tentang korelasi agar dapat mengetahui suatu hubungan. Selanjutnya peneliti membuat instrumen penelitian sesuai dengan variabel yang menjadi fokus penelitian.

Setelah beberapa kali melakukan perbaikan atau revisi dari dosen pembimbing peneliti melanjutkan uji coba instrumen pada siswa agar diketahui validitas dan reliabilitas instrument, sehingga dapat menyeleksi item-item yang disusun dengan membuang soal tidak valid dan mempertahankan item valid. Item-item terpilih ini merupakan pertanyaan atau pernyataan yang nantinya dijadikan penelitian. Persiapan dilanjutkan dengan memasukkan item-item dalam google form dan membuat tampilan yang menarik agar dapat mendorong antusias siswa mengisi kuesioner. Setelah segala persiapan dirasa cukup, peneliti menghubungi pihak sekolah untuk melaksanakan penelitian. 


\subsubsection{Tahap II Pelaksanaan}

Pada tahap ini peneliti bekerja sama dengan guru BK di SMAN 1 Wates untuk menyalurkan angket penelitian pada siswa, sebab kegiatan belajar mengajar dialihkan ke rumah. Angket yang digunakan dalam pengumpulan data disebarkan melalui google form dengan media google classroom. Sebagai upaya untuk mendorong kontribusi siswa dalam pengisian angket, peneliti menambahkan keterangan-keterangan dalam bahasa persuasif yang dapat menggerakkan partisipasi siswa pada penelitian ini. Selain itu, peneliti juga menyertakan link video youtube apabila siswa belum memahami tata cara atau tujuan dalam mengisi angket penelitian.

\subsubsection{Tahap III Pengolaan Data}

Setelah data terkumpul dilanjutkan pengolahan data menggunakan uji regresi, hal ini bertujuan untuk mengetahui hasil penelitian yang berkaitan dengan hubungan yang terdapat pada masing-masing variabel. Setiap variabel akan digali secara jelas, sehingga diketahui seberapa besar variabel penelitian tersebut berpengaruh pada siswa.

\subsubsection{Deskripsi Data}

Deskripsi data akan menjelaskan setiap variabel yang diteliti, sehingga dapat diketahui seberapa besar atau banyak siswa di SMAN 1 Wates yang memiliki dukungan sosial, efikasi diri, dan motivasi berprestasi.

\subsubsection{Deskripsi Data Dukungan Sosial}

Hasil analisis skala dukungan sosial mendeskripsikan secara umum tentang dukungan sosial yang dimiliki oleh siswa SMAN 1 Wates. Pengkategorian ini dihitung secara manual yang dilanjutkan menggunakan SPSS dengan hasil data di bawah ini:

Tabel 1. Hasil Analisis Deskriptif Dukungan Sosial

\begin{tabular}{lcccc}
\hline Kategori Skor & Rentang Skor & Jumlah Responden & Persentase & Klasifikasi \\
\hline Rendah & $<43$ & 0 & 0 & Tidak ada \\
Sedang & $44-65$ & 47 & $25,7 \%$ & Sedikit \\
Tinggi & $>66$ & 136 & $74,3 \%$ & Banyak \\
& Total & 183 & $100 \%$ & \\
\hline
\end{tabular}

Pada tabel 4.2 hasil penjabaran analisis deskriptif mengenai dukungan sosial dapat memperlihatkan dukungan sosial siswa SMAN 1 Wates. Diketahui bahwa dukungan sosial siswa SMAN 1 Wates memiliki kategori sedang dan tinggi. Siswa dengan kategori sedang berjumlah 47 orang dengan persentase sebesar $25,7 \%$, sehingga dapat diklasifikasikan sedikit. Sedangkan, siswa yang memperoleh kategori skor tinggi berjumlah 136 orang dengan persentase 74,3\%, hal ini termasuk dalam klasifikasi banyak. Berdasarkan hasil data di atas dapat disimpulkan bahwa sebagian besar siswa SMAN 1 Wates memiliki dukungan sosial yang tergolong dalam kategori tinggi. 


\subsubsection{Deskripsi Data Efikasi Diri}

Hasil analisis skala efikasi diri digunakan untuk mendiskripsikan data tentang efikasi diri pada siswa SMAN 1 Wates secara umum. Kategorisasi diperoleh dari penghitungan secara manual yang dilanjutkan menggunakan SPSS dengan hasil berikut ini:

Tabel 2. Hasil Analisis Deskriptif Efikasi Diri

\begin{tabular}{lcccc}
\hline Kategori Skor & Rentang Skor & Jumlah Responden & Persentase & Klasifikasi \\
\hline Rendah & $<47$ & 0 & 0 & Tidak ada \\
Sedang & $48-71$ & 30 & $16,4 \%$ & Sangat Sedikit \\
Tinggi & $>72$ & 153 & $83,6 \%$ & Sangat Banyak \\
& Total & 183 & $100 \%$ & \\
\hline
\end{tabular}

Pada tabel 2 hasil dari penjabaran analisis deskriptif tentang efikasi diri dapat menggambarkan efikasi diri siswa SMAN 1 Wates. Atas dasar data di atas efikasi diri yang dimiliki siswa SMAN 1 Wates termasuk dalam kategori skor sedang dan tinggi. Siswa dengan kategori sedang memiliki klasifikasi sedikit karena jumlah siswa dalam kategori ini yaitu 30 orang dengan persentase $16,4 \%$. Sedangkan, siswa dengan kategori tinggi berjumlah 153 orang memiliki persentase 74,3\%, dengan ketentuan klasifikasi yang tergolong banyak. Berdasarkan kategori skor yang ditunjukkan, dapat disimpulkan bahwa sebagian besar siswa SMAN 1 Wates memiliki efikasi diri yang tergolong tinggi.

\subsubsection{Deskripsi Data Motivasi Berprestasi}

Hasil analisis skala motivasi berprestasi mendeskripsikan tentang motivasi berprestasi yang dimiliki oleh siswa SMAN 1 Wates secara umum. Pengkategorian ini dihitung secara manual dan dibantu dengan SPSS dengan hasil data berikut ini:

Tabel 3. Hasil Analisis Deskriptif Motivasi Berprestasi

\begin{tabular}{lcccc}
\hline Kategori Skor & Rentang Skor & Jumlah Responden & Persentase & Klasifikasi \\
\hline Rendah & $<35$ & 0 & 0 & Tidak ada \\
Sedang & $36-53$ & 37 & $20,2 \%$ & Sedikit \\
Tinggi & $>54$ & 146 & $79,8 \%$ & Banyak \\
& Total & 183 & $100 \%$ & \\
\hline
\end{tabular}

Pada tabel 3 hasil analisis deskriptif motivasi berprestasi dapat memperlihatkan motivasi berprestasi yang dimiliki siswa SMAN 1 Wates. Hal ini ditunjukkan melalui kategori skor yang dihasilkan, siswa dengan kategori sedang terdapat 37 orang dengan presentase 20,2\%, sehingga dapat diklasifikasikan sedikit. Sedangkan, siswa dengan kategori skor tinggi berjumlah 146 orang dengan presentase $74,3 \%$. Hasil presentase tersebut, apabila dilihat dari ketentuan klasifikasi maka dapat digolongkan banyak. Berdasarkan pemaparan di atas, dapat disimpulkan bahwa sebagian besar siswa SMAN 1 Wates memiliki motivasi berprestasi dengan kategori tinggi. 


\subsection{Pembahasan}

Penelitian yang dilaksanakan di SMAN 1 Wates bertujuan untuk menggali hubungan antar variabel yang diteliti. Dukungan sosial merupakan suatu bantuan secara lisan maupun perbuatan untuk penerimanya, dalam hal ini konteks penerima dukungan sosial lebih mengarah ke siswa. Gottlieb (dalam Kusuma, dkk, 2015) mengemukakan bahwa dukungan seringkali berasal dari orang-orang terdekat yang akrab dengan siswa. Orang terdekat siswa umumnya orang-orang yang sering berkomunikasi dengan siswa, sehingga orang tersebut berada di lingkup sosial siswa. Menurut Santrock (2008) hubungan siswa dengan orang tua, teman, guru, dan lainnya dapat mempengaruhi pencapaian siswa. Hal ini menunjukkan bahwa dukungan yang seringkali diberikan oleh orang-orang mampu memberikan dampak positif pada prestasi dan motivasi siswa. Diketahui bahwa dukungan sosial yang dimiliki siswa SMAN 1 Wates mayoritas termasuk dalam kategori tinggi. Nilai signifikansi yang diperoleh pada uji $\mathrm{T}$ menunjukkan bahwa hipotesis awal penelitian ditolak dan hipotesis akhir penelitian diterima. Setelah dilakukan analisis data dapat disimpulkan bahwa adanya hubungan yang signifikan dan positif antara dukungan sosial dengan motivasi berprestasi. Hal ini juga dibuktikan dari penelitian Kusuma, dkk (2015) yang menyatakan adanya hubungan positif dan signifikan antara dukungan sosial dengan motivasi berprestasi.

Selain dari faktor sosial, peneliti juga menggali dari faktor pribadi yang berhubungan dengan keyakinan seseorang atau biasa disebut dengan efikasi diri. Seseorang atau siswa akan aktif pada berbagai kegiatan-kegiatan sebagai bentuk menampilkan efikasi diri. Menurut Riyanti (dalam Geon, 2016) menyebutkan bahwa pentingnya efikasi diri dapat berpengaruh pada motivasi, tingkah laku, dan afeksi individu ketika melaksanakan suatu pekerjaan. Sesuai pemaparan sebelumnya, dapat diketahui bahwa efikasi diri memiliki pengaruh dengan motivasi. Selain itu, menurut Rustika (2012) menyebutkan bahwa aspek kehidupan yang dipengaruhi oleh efikasi diri salah satunya yaitu prestasi. Hal ini menunjukkan bahwa efikasi diri memiliki pengaruh pada prestasi. Berdasarkan paparan tersebut, dapat disimpulkan bahwa efikasi diri berpengaruh pada motivasi dan prestasi siswa. Pada penelitian ini, hasil uji t yaitu hipotesis akhir dalam penelitian ini disetujui. Secara keseluruhan dapat disimpulkan bahwa terdapat hubungan yang signifikan dan positif antara efikasi diri dengan motivasi berprestasi siswa. Keterkaitan tersebut didukung dari penelitian Nadiya, dkk (2021) juga mengemukakan bahwa terdapat hubungan positif dan signifikan antara self efficacy dengan motivasi berprestasi.

Motivasi berprestasi penting bagi siswa karena dengan adanya dorongan, kegiatan belajar siswa tidak hanya dijadikan sebagai formalitas melainkan makna utama belajar dilakukan untuk mencapai hasil tertentu. Santrock (2003) menjelaskan bahwa bisa atau tidaknya remaja beradaptasi dengan akademis dan tekanan dari lingkungan besar ditentukan dari faktor motivasi dan psikologis. Sesuai pernyataan sebelumnya, motivasi merupakan suatu aspek yang dapat mempengaruhi tindakan seseorang. Motivasi berprestasi dapat dipengaruhi oleh berbagai faktor, penelitian ini akan menggali hubungan antara dukungan sosial dan efikasi diri terhadap motivasi berprestasi. Bandura (dalam Santrock, 2008) menyatakan bahwa efikasi diri merupakan faktor penting yang mempengaruhi prestasi siswa. Hal ini memperlihatkan adanya hubungan antar komponen tersebut. Selain faktor internal, pada penelitian ini juga menggali faktor eksternal yang dapat mempengaruhi motivasi berprestasi yaitu dukungan sosial. Desmita (2009) menyebutkan bahwa siswa mempunyai kebutuhan yang dapat mempengaruhi pendidikannya berupa kebutuhan kasih sayang dan penghargaan. 
Pernyataan tersebut menerangkan bahwa dukungan sosial akan memotivasi siswa dalam melaksanakan tugas-tugas sebagai pelajar. Pada penelitian Manuaba \& Susilawati (2019) memaparkan bahwa adanya hubungan positif dan signifikan antara dukungan sosial dan efikasi diri dengan motivasi berprestasi. Hal ini memperkuat hasil penelitian ini yang menyebutkan bahwa tingkat motivasi berprestasi siswa SMAN 1 Wates termasuk dalam kategori tinggi. Sementara itu, hasil uji koefisien determinasi ditemukan $45,4 \%$ pengaruh yang diberikan dari dukungan sosial dan efikasi diri, sedangkan $54,6 \%$ besar hubungan variabel motivasi berprestasi diperoleh oleh faktor lain. Kemudian, untuk hasil nilai signifikansi diperoleh 0,001 <0,05. Berdasarkan paparan tersebut, dapat disimpulkan bahwa terdapat hubungan positif dan signifikan antara dukungan sosial dan efikasi diri secara bersama-sama terhadap motivasi berprestasi siswa SMAN 1 Wates.

\section{Simpulan}

Hasil penelitian yang telah dilaksanakan di SMAN 1 Wates maka dapat diambil kesimpulan sebagai berikut : (1) Terdapat hubungan positif dan signifikan antara dukungan sosial dengan motivasi berprestasi. (2) Terdapat hubungan positif dan signifikan antara efikasi diri dengan motivasi berprestasi. (3) Terdapat hubungan yang signifikan dan positif antara dukungan sosial dan efikasi diri secara bersama-sama terhadap motivasi berprestasi. (4) Terdapat hubungan antara variabel independen terhadap variabel dependen dalam penelitian ini sebesar $45,4 \%$.

\section{Daftar Rujukan}

Budiarto, D. A. (2019). Hubungan Antara Dukungan Sosial Dan Resiliensi Dengan Motivasi Berprestasi Pada Remaja Yang Memiliki Orangtua Tunggal. Doctoral Dissertation: Universitas Islam Sultan Agung.

Desmita. (2009). Psikologi Perkembangan Peserta Didik. Bandung: Remaja Rosdakarya.

Geon, S. A. B.(2016). Hubungan Antara Efikasi Diri dan Determinasi Diri Siswa Kelas X SMA Charitas. Psiko Edukasi, 14(1), 28-38.

Hurlock, E. B. (1980). Psikologi Perkembangan Suatu Pendekatan Sepanjang Rentan Kehidupan. Terjemahan Istiwidayanti \& Soedjarwo. Jakarta: Erlangga.

Intan,G. (2020). Skor PISA Menurun, Jokowi Soroti Masalah Pendidikan Indonesia. Voaindonesia. (Online), Https://Www.Voaindonesia.Com/A/Skor-Pisa-Menurun-Jokowi-Soroti-Masalah-PendidikanIndonesia/5358904.Html.

Kusuma, T. A., Tjalla, A., \& Setyowati, E. (2015). Hubungan Antara Dukungan Sosial Dan Motivasi Berprestasi Siswa Kelas VII Di Madrasah Tsanawiyah Negeri 8 Jakarta Barat. Insight: Jurnal Bimbingan Konseli.

Manuaba, I. B. P. A., \& Susilawati, L. K. P. A. (2019). Hubungan Dukungan Sosial Dan Efikasi Diri Dengan Motivasi Berprestasi Pada Remaja Awal Dan Tengah Yang Tinggal Di Panti Asuhan Di Bali. Jurnal Psikologi Udayana, 6(01), 161-170.

Nadiya, O., Afiati, E., \& Nurmala, M. D. (2021). Hubungan Self Efficacy Dengan Motivasi Berprestasi Pada Siswa Kelas XI SMA Negeri 1 Cilegon Dan Implikasi Bagi Program Bimbingan Dan Konseling. Coution: Journal Of Counseling And Education, 2(1), 51-57.

Nate, K. U. (2019). Hubungan Antara Dukungan Sosial Dengan Motivasi Berprestasi Pada Siswa Sma Perguruan Rakyat 2 Jakarta. Doctoral Dissertation : Universitas Islam Sultan Agung.

Rosa, V. \& Efendi, D. A . (2020). Akibat Pandemi, 40 Persen Pelajar Indonesia Kehilangan Motivasi Belajar. Suara.Com. (Online), Https://Www.Suara.Com/Health/2020/12 /16/141248/Akibat-Pandemi-40Persen-Pelajar-Indonesia-Kehilangan-Motivasi-Belajar.

Rustika, I. M. (2012). Efikasi diri: tinjauan teori Albert Bandura. Buletin Psikologi, 20(1-2), 18-25.

Santrock, J. W. (2003). Adolescence Perkembangan Remaja. Terjemahan Shinto B Adelar \& Sherly Saragih. Jakarta: Erlangga.

Santrock, J. W. (2008). Psikologi Pendidikan. Jakarta: Kencana. 
Jurnal Pembelajaran, Bimbingan, dan Pengelolaan Pendidikan, 1(10), 2021, 838-846

Suriansyah, A. (2011). Landasan Pendidikan. Banjarmasin: Comdes.

Susanto, A. (2018). Bimbingan Dan Konseling Di Sekolah Konsep, Teori, dan Aplikasinya. Jakarta: Prenadamedia Group. 